\title{
Enrichment for Cases of African-American Patients with Pathogenic TTR V142I Variant in the TOPCAT Trial
}

Nikolaos Papoutsidakis, MD, $\mathrm{PhD}^{1 *}$, Neeru Gandotra, $\mathrm{PhD}^{2 *}$, Edward Miller, MD, $\mathrm{PhD}^{1}$, Michael F. Murray, $\mathrm{MD}^{2}$, Curt Scharfe, MD, $\mathrm{PhD}^{2 \wedge}$, Daniel Jacoby, $\mathrm{MD}^{1 \wedge}$

${ }^{1}$ Department of Internal Medicine, Cardiovascular Medicine, Yale School of Medicine, New Haven, CT

${ }^{2}$ Department of Genetics, Yale School of Medicine, New Haven, CT.

*Equal contribution

${ }^{\wedge}$ Corresponding authors

\begin{abstract}
Transthyretin cardiac amyloidosis (ATTR-CA) is a treatable cause of heart failure with a hereditary form that disproportionally affects patients of West African ancestry. The clinical management of ATTR-CA has dramatically changed in the past five years, with rapidly evolving diagnostic approaches and life-prolonging therapies. The TTR variant c.424G>A, p.V142I (aka V122I) is pathogenic and occurs in 3-4\% of individuals of West African ancestry. Despite its high frequency, V142I ATTR-CA is often unrecognized due to variable clinical penetrance, limited knowledge, and lack of inexpensive non-invasive diagnostic tests. Currently unknown is which TTR V142I carriers will progress to heart failure and at what age. Here we studied the prevalence of TTR V142I among a random cohort of African-American patients enrolled in the Treatment of Preserved Cardiac Function Heart Failure With an Aldosterone Antagonist Trial (TOPCAT). Three of the 26 HFpEF patients (11.5\%) studied carried the pathogenic TTR V142I variant. While we cannot conclude at this point that TTR V142I was the underlying cause of the clinical phenotype in these patients, our results suggest that rapid TTR V142I genotyping, in combination with heart imaging, could have immediate clinical utility for identifying under-/mis-diagnosed HFpEF patients.
\end{abstract}


medRxiv preprint doi: https://doi.org/10.1101/2020.10.14.20201046; this version posted October 16, 2020. The copyright holder for this preprint (which was not certified by peer review) is the author/funder, who has granted medRxiv a license to display the preprint in perpetuity.

It is made available under a CC-BY-NC 4.0 International license .

\section{Introduction}

Transthyretin cardiac amyloidosis (ATTR-CA) is an increasingly recognized cause of left ventricular hypertrophy and heart failure. Pathogenic DNA variants in the TTR gene confer an autosomal dominant risk for ATTR, with clinical manifestations that precede diagnosis often by years[1]. One of the most frequent pathogenic TTR variants (c.424G>A, p.V142I, also notated as V122I) occurs almost exclusively in individuals of West African descent[2]. An estimated 1.5 million African Americans (3.4\%) in the United States are heterozygous for TTR V142I[2]. Heart failure with preserved ejection fraction (HFpEF) is a heterogeneous clinical phenotype that accounts for approximately half of newly diagnosed cases of heart failure in the US per year and for which there are currently no evidence based medical therapies. Recent studies suggested that ATTR cardiomyopathy prevalence amongst HFpEF patients is much higher than previously thought, due to under-recognition[2, 3]. This has important implications for HFpEF clinical trials as treatment effects are likely to differ between idiopathic and ATTRrelated HFpEF. Here we describe our investigation of the prevalence of TTR V142I among a random cohort of African-American patients enrolled in the Treatment of Preserved Cardiac Function Heart Failure With an Aldosterone Antagonist Trial (TOPCAT)[4].

\section{Material and Methods}

We requested all available trial data and de-identified DNA samples from patients enrolled in TOPCAT who self-identified as black from the BIOLINCC repository. TTR gene variants were identified using clinical exome sequencing and confirmed using bidirectional Sanger sequencing. The genetic findings were correlated with clinical outcome data for each subject. All but one of the samples originated from US sites. This study was overseen by the institutional review board at Yale University.

\section{Results}

The BIOLINCC repository was able to provide biospecimens with extractable DNA for only 26 TOPCAT black subjects, possibly due to elapsed time from the TOPCAT trial. Three of $26 \mathrm{HFpEF}$ patients studied carried the pathogenic TTR V142I variant (Table 1). 
medRxiv preprint doi: https://doi.org/10.1101/2020.10.14.20201046; this version posted October 16, 2020. The copyright holder for this preprint (which was not certified by peer review) is the author/funder, who has granted medRxiv a license to display the preprint in perpetuity.

It is made available under a CC-BY-NC 4.0 International license .

The enrichment of TTR V142I in this cohort of HFpEF patients (11.5\%) was increased compared to the general African-American population (3.4\%). Analysis of trial data showed that all three subjects positive for TTR V142I were assigned in the placebo group, and two out of three patients (66\%) reached the primary end-point (composite of death from cardiovascular causes, aborted cardiac arrest, or hospitalization for the management of heart failure). In comparison, of the 302 black TOPCAT patients for whom trial data were available, $34.4 \%(n=104)$ reached the primary end-point.

\section{Discussion}

We found a significant proportion of African-American HFpEF subjects (11.5\%) carried the TTR V142I variant in this random sample from TOPCAT, in spite of efforts to specifically exclude infiltrative cardiomyopathy at the point of enrollment[4]. While we cannot say for certain, it is possible that these three patients suffered from HFpEF driven by ATTR-CA at the time of enrollment. ATTR-CA runs an insipid course, with TTR amyloid tissue deposition often preceding heart failure diagnosis by years[1, 2]. Our findings are consistent with prior findings suggesting that ATTR-CA can be missed even after current approaches to strict clinical trial screening. Our sample cohort was significantly enriched in females, for unknown reasons. This could potentially alter patients' clinical characteristics, as inherited ATTR-CA often expresses at a later age in females. Whether enrolling unidentified ATTR-CA patients in clinical HFpEF trials adversely affects our ability to identify effective treatments is a relevant question.

There has been a series of negative HFpEF trials over the years leading to near complete absence of effective medical treatment for HFpEF. Could it be possible that occult ATTR-CA has been one of the drivers of the extended HFpEF therapy drought? That depends on whether we believe that ATTR-CA patients would have a different response to medical therapy than "run-of-the-mill" HFpEF. There is general agreement that angiotensin pathway modification and beta-blockade are at best ineffective and at worst counterproductive in the treatment of patients with ATTR-CA. Whether aldosterone receptor antagonists (studied in TOPCAT) react differently is at present impossible to say. In any event, ATTR screening was not part of previous studies and 
merits consideration for HFpEF and, potentially, even HFrEF[5] clinical trials going forward. For populations shown to be enriched with ATTR (African-Americans middleaged or older, or elderly men regardless of race with $\mathrm{HFpEF}$ ) we would contend that it is worthwhile to explore point-of-care diagnostic strategies, employing 99mTcpyrophosphate (PYP) cardiac scanning and/or rapid TTR V142I genetic testing when enrolling for clinical trials for HFpEF.

\section{Funding}

This work was in parts supported by institutional funds at Yale University and a Connecticut Innovations Biopipeline program award (CS).

\section{References}

1. Papoutsidakis N, Miller EJ, Rodonski A, Jacoby D. Time course of common clinical manifestations in patients with transthyretin cardiac amyloidosis: Delay from symptom onset to diagnosis. J Card Fail 2018:24(2): 131-133.

2. Buxbaum JN, Ruberg FL. Transthyretin V122I (pV142I)* cardiac amyloidosis: An agedependent autosomal dominant cardiomyopathy too common to be overlooked as a cause of significant heart disease in elderly african americans. Genet Med 2017:19(7): 733-742.

3. Gonzalez-Lopez E, Gallego-Delgado M, Guzzo-Merello G, de Haro-Del Moral FJ, Cobo-Marcos M, Robles C, Bornstein B, Salas C, Lara-Pezzi E, Alonso-Pulpon L et al. Wild-type transthyretin amyloidosis as a cause of heart failure with preserved ejection fraction. Eur Heart J 2015:36(38): 2585-2594.

4. Pitt B, Pfeffer MA, Assmann SF, Boineau R, Anand IS, Claggett B, Clausell N, Desai AS, Diaz R, Fleg JL et al. Spironolactone for heart failure with preserved ejection fraction. N Engl J Med 2014:370(15): 1383-1392.

5. Buxbaum J, Jacobson DR, Tagoe C, Alexander A, Kitzman DW, Greenberg B, Thaneemit-Chen S, Lavori P. Transthyretin v122i in african americans with congestive heart failure. J Am Coll Cardiol 2006:47(8): 1724-1725. 
Table 1: Demographic and clinical data from 26 TOPCAT patients and genetic findings.

\begin{tabular}{|c|c|c|c|c|c|c|c|c|c|c|c|c|c|}
\hline Random ID & 710811 & 875425 & 343485 & 220741 & 948460 & 233830 & 487405 & 990265 & 886315 & 415485 & 313427 & 7476332 & 988134 \\
\hline $\begin{array}{c}\text { Pathogenic TTR } \\
\text { Variant }\end{array}$ & \begin{tabular}{|c|}
$c .424 G>A$ \\
(p.V142I)
\end{tabular} & $\begin{array}{l}\text { c. } 424 G>A \\
(p . V 142 l)\end{array}$ & $\begin{array}{l}\text { c.424G>A } \\
\text { (p.V142I) }\end{array}$ & - & - & - & - & - & - & - & - & - & - \\
\hline Gender & $\mathrm{F}$ & $M$ & $F$ & $\mathrm{~F}$ & $\mathrm{~F}$ & $\mathrm{~F}$ & $\mathrm{~F}$ & M & $M$ & $\mathrm{~F}$ & M & $\mathrm{F}$ & $\mathrm{F}$ \\
\hline $\begin{array}{c}\text { Age Entering } \\
\text { Study }\end{array}$ & 70's & 60 's & 50 's & 80 's & 60 's & 80 's & 60 's & 60 's & 70 's & 60 's & 50 's & 60 's & 50 's \\
\hline TOPCAT group* & PCB & PCB & PCB & SP & PCB & PCB & PCB & PCB & SP & SP & SP & PCB & PCB \\
\hline $\begin{array}{l}\text { Primary } \\
\text { Endpoint } \\
\text { reached }\end{array}$ & $\mathrm{N}$ & Y & Y & $\mathrm{N}$ & Y & Y & Y & Y & Y & $\mathrm{N}$ & $\mathrm{N}$ & $\mathrm{N}$ & $\mathrm{N}$ \\
\hline $\begin{array}{c}\text { Any Cause } \\
\text { death }\end{array}$ & $\mathrm{N}$ & $\mathrm{N}$ & $\mathrm{N}$ & $\mathrm{N}$ & Y & $\mathrm{N}$ & $\mathrm{N}$ & Y & $\mathrm{N}$ & $\mathrm{N}$ & $\mathrm{N}$ & $\mathrm{N}$ & $\mathrm{N}$ \\
\hline $\mathrm{SBP}(\mathrm{mm} \mathrm{Hg})$ & 160 & 118 & 133 & 126 & 120 & 141 & 136 & 122 & 131 & 150 & 126 & 97 & 118 \\
\hline $\mathrm{DBP}(\mathrm{mm} \mathrm{Hg})$ & 52 & 75 & 71 & 70 & 69 & 69 & 72 & 82 & 61 & 58 & 88 & 65 & 60 \\
\hline Use of BB & Y & Y & $\mathrm{Y}$ & Y & Y & $\mathrm{Y}$ & Y & Y & Y & $\mathrm{Y}$ & Y & Y & Y \\
\hline Use of CCB & Y & Y & $\mathrm{N}$ & Y & $\mathrm{N}$ & $\mathrm{N}$ & Y & Y & $\mathrm{N}$ & Y & Y & $\mathrm{N}$ & Y \\
\hline Use of Diuretic & Y & Y & Y & Y & Y & Y & Y & Y & Y & Y & Y & Y & Y \\
\hline $\begin{array}{c}\text { Use of ACE-I or } \\
\text { ARB }\end{array}$ & Y & Y & $\mathrm{Y}$ & $\mathrm{N}$ & $\mathrm{N}$ & Y & Y & Y & Y & $\mathrm{N}$ & Y & Y & Y \\
\hline LVH on ECG & $Y$ & $\mathrm{~N}$ & $\mathrm{~N}$ & & $\mathrm{~N}$ & Y & $\mathrm{N}$ & $\mathrm{N}$ & $\mathrm{N}$ & $\mathrm{N}$ & $\mathrm{N}$ & & $\mathrm{N}$ \\
\hline $\begin{array}{c}\text { Interventricular } \\
\text { septum } \\
\text { thickness }\end{array}$ & - & - & 1.1 & 0.9 & - & 1.2 & 1.2 & - & 1.3 & 1.2 & 1.1 & 1.1 & - \\
\hline $\begin{array}{c}\text { Posterior wall } \\
\text { thickness }\end{array}$ & - & - & 1.1 & 0.9 & - & 1.1 & 1.1 & - & 1.1 & 1.2 & 1.1 & 1.0 & - \\
\hline LV Mass & - & - & 197 & 166 & - & 179 & 245 & - & 213 & 272 & 154 & 217 & - \\
\hline $\begin{array}{c}\text { Ejection Fraction } \\
\text { (prior to } \\
\text { enrolling) }\end{array}$ & 60 & 50 & 52 & 60 & 70 & 60 & 76 & 50 & 45 & 60 & 45 & 50 & 48 \\
\hline $\begin{array}{c}\text { Longitudinal } \\
\text { Strain }\end{array}$ & - & - & -13.29 & -18.61 & - & - & -15.62 & - & - & $\mid-18.28$ & -10.39 & -18.63 & - \\
\hline Hypertension & Y & $Y$ & $\mathrm{Y}$ & Y & Y & $\mathrm{Y}$ & Y & Y & Y & Y & Y & Y & Y \\
\hline Atrial fibrillation & $\mathrm{N}$ & Y & Y & $\mathrm{N}$ & $\mathrm{N}$ & Y & $\mathrm{N}$ & $\mathrm{N}$ & Y & $\mathrm{N}$ & Y & $\mathrm{N}$ & $\mathrm{N}$ \\
\hline
\end{tabular}

${ }^{*} \mathrm{PCB}=$ Placebo, $\mathrm{SP}=$ Spironolactone 
Table 1 (continued)

\begin{tabular}{|c|c|c|c|c|c|c|c|c|c|c|c|c|c|}
\hline Random ID & 954421 & 689847 & 437794 & 386230 & 302130 & 637663 & 442800 & 555747 & 7371036 & 6715887 & 955499 & 908592 & 339794 \\
\hline Pathogenic TTR Variant & - & - & - & - & - & - & - & - & - & - & - & - & - \\
\hline Gender & $\mathrm{F}$ & $\mathrm{F}$ & $\mathrm{F}$ & $\mathrm{F}$ & M & $\mathrm{F}$ & $\mathrm{F}$ & $\mathrm{F}$ & $\mathrm{F}$ & $\mathrm{F}$ & $M$ & $\mathrm{~F}$ & $\mathrm{~F}$ \\
\hline Age Entering Study & 60 's & 60 's & 50 's & 60 's & 60 's & 70 's & 60 's & 70's & 50 's & 60 's & 50 's & 60 's & 60 's \\
\hline TOPCAT group* & SP & SP & PCB & SP & SP & SP & PCB & SP & PCB & PCB & PCB & SP & SP \\
\hline Primary Endpoint reached & $\mathrm{N}$ & Y & $\mathrm{N}$ & $\mathrm{Y}$ & $\mathrm{Y}$ & $\mathrm{Y}$ & Y & $\mathrm{Y}$ & Y & $\mathrm{Y}$ & $\mathrm{Y}$ & Y & $\mathrm{N}$ \\
\hline Any Cause death & $\mathrm{N}$ & $\mathrm{N}$ & $\mathrm{N}$ & $\mathrm{N}$ & $\mathrm{Y}$ & $\mathrm{N}$ & $\mathrm{N}$ & $\mathrm{N}$ & $\mathrm{N}$ & $\mathrm{Y}$ & $\mathrm{N}$ & $\mathrm{N}$ & $\mathrm{N}$ \\
\hline $\mathrm{SBP}(\mathrm{mm} \mathrm{Hg})$ & 143 & 138 & 133 & 135 & 146 & 136 & 147 & 124 & 110 & 119 & 121 & 154 & 128 \\
\hline $\mathrm{DBP}(\mathrm{mm} \mathrm{Hg})$ & 73 & 70 & 92 & 90 & 90 & 58 & 85 & 70 & 64 & 63 & 85 & 96 & 58 \\
\hline Use of BB & $\mathrm{Y}$ & Y & Y & $\mathrm{N}$ & Y & $\mathrm{Y}$ & Y & Y & $Y$ & $\mathrm{Y}$ & $\mathrm{Y}$ & Y & $\mathrm{Y}$ \\
\hline Use of CCB & $\mathrm{Y}$ & Y & $Y$ & $\mathrm{~N}$ & $\mathrm{~N}$ & $\mathrm{Y}$ & Y & $\mathrm{N}$ & $Y$ & $\mathrm{Y}$ & $\mathrm{N}$ & $\mathrm{Y}$ & $\mathrm{Y}$ \\
\hline Use of Diuretic & $\mathrm{Y}$ & Y & Y & Y & $\mathrm{Y}$ & Y & Y & $\mathrm{Y}$ & $\mathrm{Y}$ & $\mathrm{Y}$ & Y & Y & $\mathrm{Y}$ \\
\hline Use of ACE-I or ARB & $Y$ & $\mathrm{~N}$ & Y & Y & $\mathrm{N}$ & $Y$ & Y & $\mathrm{N}$ & $\mathrm{Y}$ & Y & Y & Y & Y \\
\hline LVH on ECG & $\mathrm{N}$ & $\mathrm{N}$ & Y & Y & $\mathrm{N}$ & $\mathrm{Y}$ & $\mathrm{N}$ & $\mathrm{N}$ & $\mathrm{N}$ & Y & $\mathrm{N}$ & - & $\mathrm{N}$ \\
\hline $\begin{array}{c}\text { Interventricular septum } \\
\text { thickness }\end{array}$ & 1.4 & 1.2 & 1.6 & 1.3 & 1.4 & - & - & 1.1 & - & - & - & 1.5 & - \\
\hline Posterior wall thickness & 1.4 & 1.1 & 1.6 & 1.2 & 1.5 & - & - & 1.1 & - & - & - & 1.3 & - \\
\hline LV Mass & 317 & 141 & 276 & 227 & 336 & - & - & 198 & - & - & - & 321 & - \\
\hline $\begin{array}{c}\text { Ejection Fraction (prior to } \\
\text { enrolling) }\end{array}$ & 60 & 72 & 50 & 45 & 45 & 67 & 58 & 65 & - & - & - & - & - \\
\hline Longitudinal Strain & -17.83 & -19.43 & -12.96 & -13.50 & -13.62 & - & - & -13.21 & - & - & - & - & - \\
\hline Hypertension & Y & $\mathrm{Y}$ & Y & Y & Y & Y & $\mathrm{Y}$ & $\mathrm{Y}$ & $\mathrm{Y}$ & Y & Y & $\mathrm{Y}$ & $Y$ \\
\hline Atrial fibrillation & $\mathrm{N}$ & $\mathrm{N}$ & $\mathrm{N}$ & $\mathrm{N}$ & $\mathrm{N}$ & $\mathrm{N}$ & $\mathrm{N}$ & $Y$ & $\mathrm{~N}$ & $\mathrm{~N}$ & $\mathrm{~N}$ & $\mathrm{Y}$ & $\mathrm{N}$ \\
\hline
\end{tabular}

